\title{
Review
}

\section{Pathogenesis of Graves' Disease: Molecular Analysis of Anti-Thyrotropin Receptor Antibodies}

\author{
TAKASHI AKAMIZU, TORU MORI*, AND KAZUWA NAKAO \\ Department of Medicine \& Clinical Science, *Department of Laboratory Medicine, \\ Kyoto University Graduate School of Medicine, Kyoto 606, Japan
}

\section{Introduction}

Graves' disease is an autoimmune disease characterized by hyperthyroidism, goiter and extrathyroidal manifestations, such as exophthalmos $[1,2]$. Autoantibodies to the TSH receptor (TSHR) have been detected in patients with Graves' disease and stimulating antibodies to TSHR are believed to induce hyperthyroidism [3, 4]. Therefore, TSHR and anti-TSHR antibodies (TSHRAb) play a key role in this disease. In our previous review, we described studies on the cloning and analysis of both TSHR and TSHRAb genes [5]. This study aimed to clarify the structure, function and interaction of TSHR and TSHRAb at the molecular level. In the present review, we summarize results of recent extended molecular analysis of TSHRAb. In addition, we refer to genetic components in Graves' disease, a disease in which multiple genetic and environmental factors are thought impair immunoregulation.

\section{Causes of Graves' Disease}

There is a growing consensus that Graves' disease, similar to other autoimmune diseases, is

Received: April 7, 1997

Accepted: June 6, 1997

Correspondence to: Dr. Takashi AKAMIZU, Department of Medicine \& Clinical Science, Kyoto University School of Medicine, 54 Shogoin-Kawaharacho, Sakyo-ku, Kyoto 606, Japan

This review was written as a memorial article for the Research Encouragement Prize of the Japan Endocrine Society awarded to the author (T.A.) on July 3, 1996. multifactorial: many factors interact and produce the clinical phenotype of this disease (Fig. 1).

\section{Genetic factors}

Graves' disease is a complex disease with a significant genetic component as shown by twin studies [6] and familial aggregation, including clustering within families $[7,8]$. While the genetic basis of Graves' disease is unclear, it is believed to be polygenic. Several genetic factors associated with Graves' disease susceptibility have been identified, including sex (a five-fold higher prevalence in females), the HLA genes on chromosome $6 \mathrm{p}$ [9], the immunoglobulin heavy chain gene constant region, $\mathrm{Gm}$, on $14 \mathrm{q} 32.2$ [9], a point mutation at codon 52 of the TSHR gene on 14q31 [10], the CTLA-4 gene region on 2q33 [11], and the interleukin-1 receptor antagonist gene [12].

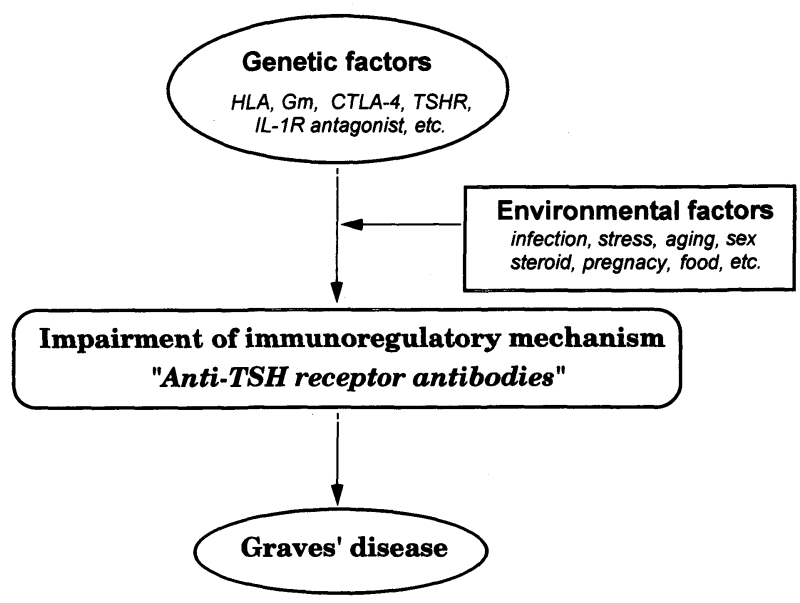

Fig. 1. Pathogenesis of Graves' disease. 
The HLA Class II association with Graves' disease has been observed in Japanese [9], Caucasian and Chinese [13] populations. In common with some other autoimmune diseases, there is strong association with HLA-DR3 [13-15], but other HLA associations with Graves' disease have shown a lack of consistency between populations [9, 13]. Roman et al. [16] observed association but no linkage between the HLA region and Graves' disease in a Caucasian population, and suggested that HLA may increase susceptibility to Graves' disease but the major genetic influence on the inheritance may lie at another locus.

Theories of autoimmunity fall into four main categories: primary immune dysregulation, failure of idiotype control, molecular mimicry, and primary lesion theory [17]. Some combine two of these, and they almost certainly overlap. In the primary lesion theory, it has been hypothesized that a change in an antigen may trigger a response in a normal immune system [17], or that a proportion of the population carries a slightly altered form of an antigen which, when combined with other genetic and environmental factors, may result in the disease phenotype [18]. TSHR is an autoantigen found in many autoimmune thyroid diseases (AITD) patients, and an association has already been observed between a point mutation of TSHR and AITD susceptibility. We have recently investigated the genetic contribution of TSHR to AITD susceptibility in the Japanese $[19,20]$. While the gene for TSHR has been cloned [5] and localized to 14 q31 [21-23], it was not genetically mapped previously. Development of a microsatellite marker for the TSHR gene is essential for evaluating its role in populations with AITD through association and linkage analyses. Therefore, we isolated a yeast artificial chromosome containing part of the TSHR gene and identified a dinucleotide repeat polymorphism near the TSHR gene (heterozygosity $=0.67$ in the Japanese). This microsatellite mapped to an $8.6 \mathrm{cM}$ interval between D14S74 and D14S55 on the long arm of the TSHR gene (heterozygosity $=0.67$ in the Japanese). Next, the microsatellite marker we identified has been used to assess the genetic contribution of the TSHR gene to AITD in a population of Japanese patients. Association studies were performed between the TSHR microsatellite and a population of 81 unrelated Japanese AITD patients. A significant increase in the frequency of allele $1(180 \mathrm{bp})$ was observed in the AITD population when compared with 50 male Japanese controls $\left(P=5.9 \times 10^{-8}\right)$. This association was highly significant in the female patients $(n=63$; $P=1.8 \times 10^{-6}$ ) and near significant in males. When the data was stratified into AITD type (Graves' disease, hypothyroid patients with thyrotropin stimulation blocking antibodies (BAb), or Hashimoto's Thyroiditis (HT)), HT ( $n=18 ; P=4.9 \times$ $\left.10^{-10}\right)$ and BAb ( $\left.\mathrm{n}=20 ; P=0.0004\right)$ but not Graves' disease showed a significant association with allele 1. These results suggest that allele 1 of the TSHR microsatellite is associated with susceptibility for AITD except Graves' disease in Japanese patients.

Point mutations have been identified in putative ligand binding regions of the extracellular domain of the TSHR gene in patients with Graves' disease [24-26], and these mutations may produce autoantigens involved in the pathogenesis of the disease. A mutation in the first position of codon 52 , resulting in the substitution of a threonine for a proline in the extracellular domain of the TSHR protein, has been shown to be significantly associated with AITD in Caucasian females [25, 26]. However, the TSHR codon 52 point mutation was not detected in any of the 81 Japanese AITD patients or the 113 Japanese controls [20].

In addition, an association has been observed between a polymorphism in the cytotoxic $\mathrm{T}$ lymphocyte associated-4 (CTLA-4) gene and susceptibility to Graves' disease in Caucasians [11], with greater significance seen in females with the disease and protective HLA genotypes. Nisticò et al. [27] found supporting evidence that CTLA-4 is associated with susceptibility to GD in Hong Kong Chinese Graves' patients. The CTLA-4 molecule, which is co-expressed with CD28 on activated Tcells, interacts with $\mathrm{B} 7$ on antigen-presenting cells to stimulate T-cell proliferation. CTLA-4 and CD28 appear to have very similar functions [28] and their genes are located at a distance of only $25-150 \mathrm{~kb}$ on 2q33 [29], so susceptibility to AITD may be associated with either of these genes or another nearby locus also in linkage disequilibrium. A recent finding revealed that $C T L A-4$ alanine-17 confers genetic susceptibility to Graves' disease and to type 1 diabetes mellitus [30]. We also evaluated Japanese AITD patients and controls for association with the CTLA-4 polymorphism [20]. While association with AITD was not observed $(P=0.15)$, 
a significant association was observed between CTLA-4 alleles of $110 \mathrm{bp}(P=0.01)$ and $106 \mathrm{bp}$ $(P=0.004)$ and susceptibility to primary hypothyroidism or idiopathic myxedema respectively.

\section{Environmental factors}

Multiple factors including infection, stress, sex steroids, pregnancy, aging and food, are known as environmental factors precipitating Graves' disease [1]. Structural similarity between infectious agents and TSHR can lead to crossover of specificity, molecular mimicry. In fact, specificity crossover has been reported between Yersinia enterocolitica and TSHR, based on the cross-reaction between Yersinia and serum from patients with Graves' disease as well as between retroviral sequences and the TSHR [1]. Regarding stress, Benvenga reported that adjunctive benzodiazepine therapy with use of antithyroid drugs decreased the incidence of relapse of the disease [31]. A large prospective study on the value of benzodiazepine in the treatment of Graves' disease is needed. The recent cloning of $\mathrm{Na} / \mathrm{I}$ symporter [32] gene might reveal the pathophysiology of JodBasedow.

\section{Immunological Mechanism}

Genetic and environmental factors disrupt immunological mechanisms to produce TSHRAb (Fig. 1). Obviously, these immunological impairments are related to a breakdown of immunological tolerance [33, 34]. Failures in immunological tolerance occur both in B cell and $\mathrm{T}$ cell systems. Removal of autoreactive $\mathrm{T}$ cells occurs in the thymus (negative selection) or in the peripheral organs (clonal deletion, clonal anergy and active suppression). Breakdown of immunological tolerance in the $\mathrm{T}$ cell system occurs in the context of particular genes such as haplotypes of HLA. In this respect, HLA and costimulator genes, such as CTLA- 4 are important genetic factors which contribute to immunological tolerance. In contrast, the mechanism of removal of autoreactive B cells is less clear. Genetic abnormalities of immunoglobulins or related proteins may be involved. One report of a linkage of $\mathrm{Gm}$ to Graves' disease [9] suggested the importance of immunoglobulin heavy chain genes as a genetic factor of the disease. Moreover, TSHRAb plays a key role in the pathophysiology of the disease. Here we summarize our molecular studies of TSHRAb, i.e., preparations of monoclonal antibodies and analysis of genes.

\section{Monoclonal TSHRAbs}

An interesting feature of TSHRAbs is their functional heterogeneity [5]. Autoantibodies which can mimic TSH actions and stimulate thyroid cells are called "thyroid stimulating antibodies (TSAbs)", while those which block TSH actions are called "thyroid-stimulation blocking antibodies (TSBAbs)". Antibodies that inhibit TSH binding to the receptor are called "TSH binding inhibitor immunoglobulins (TBIIs)". Changes in TSHRAb relationships (stimulating or inhibiting) have been observed in individual patients. Differences occur among the epitopes recognized on the TSHR protein $[5,35$, 36].

For molecular-based studies of TSHRAb, monoclonal TSHRAbs are an essential tool. The preparation of monoclonal TSHRAbs has been described previously [37-40]. We used a EBV transformation method and confirmed monoclonality by Southern blot analyses. Recently, we utilized a Magnetic Cell separator (MACS) to obtain IgG class antibodies [39]. Thus, we prepared and analyzed a series of IgG-class and IgM-class monoclonal antibodies obtained from patients with Graves' disease and primary hypothyroidism.

In previous studies using Graves' lymphocytes, surprisingly, all clones producing IgM class antibodies showed either TBII or TSAb activity, never both [5, 37]. This supports the view that TBII and TSAb are different immunoglobulins. This was the case in IgG class TSAbs $[39,40]$. In contrast, in studies using lymphocytes of hypothyroid patients, all 20 TBII positive clones obtained were positive for TSBAb activity [38]. Only two TSBAb positive clones had negative TBII activity. Although there was no significant relationship between TBII and TSBAb activity, most TBIIs and TSBAbs appear to overlap. In sum, these findings suggest that TBII in Graves' patients is different from TSAb but in myxedema patients closely overlaps with TSBAb.

Next, we attempted to elucidate the relationship between TBII and TSBAb in Graves' patients. Five 
IgM class monoclonal TBII previously prepared [37] from Graves' patients were used (Table 1) (J. Okuda and T. Akamizu, manuscript in preparation). They were isolated from EB virus-transformed lymphocytes of a patient with Graves' disease. Clone $267-1$ is a sister clone of 267-9, which was confirmed by Southern blot analysis [37]. Neither is known to have TSAb activity [37]. TSBAb activity was determined by a previously described method [38]. As shown in Table 1, 4 of 5 TBII clones had TSBAb activity. Since the normal range of TSBAb was determined to be less than $24 \%$ (mean + 2SD: $4.0+20 \%$ ), Clone 296-4 showed borderline activity, $21.3 \%$. The TSBAb activity in Graves' patients with TBII tended to be lower than that in hypothyroid patients. There was no significant relationship between TBII and TSBAb activity $(n=5, r=0.059)$. These findings do not contradict other reports using monoclonal TRAb obtained from Graves' patients [42-44]. For example, Valente et al. [42] found that potent TBIIs were TSBAbs and that TSAbs were poor TSH binding inhibitors, and Yoshida et al. [43] reported that there existed TSBAb with and without TBII, although they studied only a limited number of monoclonal TSHRAb. Our previous study using monoclonal antibodies obtained from lymphocytes of hypothyroid patients revealed that all TBII clones had TSBAb activity and all but two TSBAb clones showed TBII activity, although TBII and TSBAb activity was not significantly correlated. These findings suggested that most TBII appear to be TSBAb. In contrast, lymphocytes from Graves' patients produced either TSAb or TBII, and never both. Considering that other investigators detected a small number of clones with both TBII and TSAb $[43,45]$, we postulate here a relationship between the binding inhibitors (TBII) and the biologically heterogeneous antibodies (TSBAb and TSAb) as shown in Fig. 2. This schema is compatible with the clinical observation that TBII was altered together with TSBAb rather than TSAb in most patients with Graves' disease who developed hypothyroidism during the clinical course [46-48]. Although we used IgM class TBII in this study, we did not observe any difference by isotypes in the relationship between TSAb and TBII $[39,40]$, or TSBAb and TBII [38].

Our findings indicate that TBII is not sufficient to evaluate hyperthyroidism in Graves' disease and that TSAb might be more suitable for this
Table 1. TBII and TSBAb activities of monoclonal antibodies* $^{*}$

\begin{tabular}{lccc}
\hline Patient & Clone & TBII (\%) & TSBAb (\%) \\
\hline Graves' & $291-11$ & 23.5 & 41.3 \\
& $296-1$ & 27.8 & 31.8 \\
& $280-3$ & 24.2 & 34.6 \\
& $296-4$ & 25.5 & 21.3 \\
Hypothyroid & $267-1$ & 16.8 & 27.9 \\
& $32 \mathrm{~A}-4$ & 17.7 & 45.9 \\
& $32-5$ & 25.6 & 58.5 \\
& $\mathrm{~N}-1$ & 0.4 & 42.9 \\
& $\mathrm{~N}-2$ & -3.8 & 47.1 \\
& $\mathrm{C}-1$ & 1.3 & 5.9 \\
\hline
\end{tabular}

*TBII and TSBAb activities were measured in identical supernatants concentrated by using polyethylene glycol, and all TSBAb activity was measured at the same time. Details of patients and clones were previously described [37, 38]. 267-1 is a sister clone of 267-9 [37] and C-1 is a negative control clone that was obtained from lymphocytes of a hypothyroid patient (Patient 1 [38]). Normal values of TBII and TSBAb were less than $10 \%$ and $24 \%$, respectively.

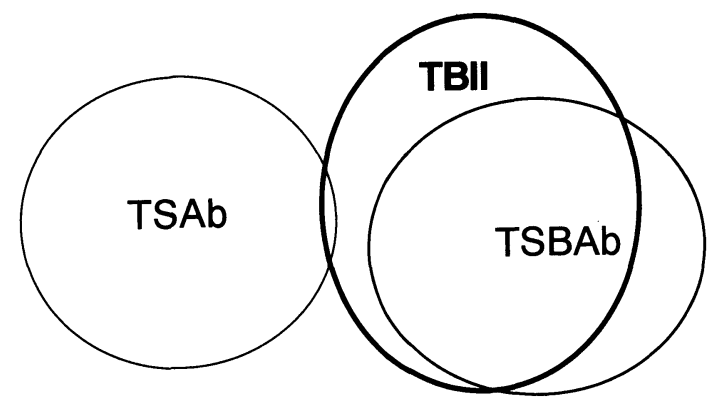

Fig. 2. Schematic representation of the relationships between heterogeneous anti-TSH receptor autoantibodies in Graves' and primary hypothyroid patients. TBII, thyrotropin binding inhibitor immunoglobulin (binding inhibitor); TSAb, thyroid stimulating antibody (biological stimulator); TSBAb, thyroid stimulation blocking antibody (biological blocker).

purpose. Although TBII and TSAb concurrently change in most patients with Graves' disease, this simultaneous alteration might merely reflect polyclonal antigen-driven expansions of autoantibody-producing cells during the disease process. Stimulation of selected clones of lymphocytes may occasionally occur and result in the discrepancy between TSAb and TBII activities [47]. Thus, the simultaneous existence of two 
Table 2. B cell clones producing TSHRAb

\begin{tabular}{|c|c|c|c|c|c|c|}
\hline \multirow{2}{*}{ Diseases } & \multirow{2}{*}{$\begin{array}{l}\text { Patients } \\
\text { number }\end{array}$} & \multirow{2}{*}{ Clones } & \multicolumn{3}{|c|}{ TSHRAb Activity (\%) } & \multirow{2}{*}{ Ig } \\
\hline & & & TBII & TSAb & TSBAb & \\
\hline \multirow[t]{5}{*}{ Graves' } & 1 & $291-11$ & 23.5 & $(-)$ & 41.3 & M \\
\hline & & $296-1$ & 27.8 & $(-)$ & 31.8 & M \\
\hline & & $296-4$ & 25.5 & $(-)$ & 21.3 & M \\
\hline & & $267-9$ & 33.2 & $(-)$ & 27.9 & M \\
\hline & & $280-3$ & 24.2 & $(-)$ & 43.3 & M \\
\hline \multirow[t]{4}{*}{ Graves' } & 2 & $141-1$ & $(-)$ & 482 & $(-)$ & M \\
\hline & & $82-1$ & $(-)$ & 483 & $(-)$ & M \\
\hline & & $71-2$ & $(-)$ & 479 & $(-)$ & M \\
\hline & & $79-4$ & $(-)$ & 543 & $(-)$ & M \\
\hline Graves' & 1 & $101-2$ & $(-)$ & 334 & $(-)$ & M \\
\hline Graves' & 3 & $22-1$ & $(-)$ & 154 & $(-)$ & M \\
\hline Graves' & 4 & B6B7 & $(-)$ & 285 & $(-)$ & G \\
\hline \multirow[t]{2}{*}{ Graves' } & 5 & F3F3 & $(-)$ & 181 & $(-)$ & G \\
\hline & & G10C5 & $(-)$ & 201 & $(-)$ & G \\
\hline Graves' & 6 & D11E2 & $(-)$ & 156 & $(-)$ & G \\
\hline \multirow[t]{2}{*}{ Hypothyroid } & 1 & $32 \mathrm{~A}-5$ & 17.7 & $(-)$ & 45.9 & G \\
\hline & & $\mathrm{N}-2$ & $(-)$ & $(-)$ & 47.1 & G \\
\hline \multirow[t]{4}{*}{ Hypothyroid } & 2 & $54-2$ & 27.0 & $(-)$ & 49.7 & G \\
\hline & & $32 \mathrm{~B}-2$ & 21.7 & $(-)$ & 46.4 & M \\
\hline & & $39-1$ & 29.0 & $(-)$ & 52.4 & M \\
\hline & & $31-3$ & 21.4 & $(-)$ & 48.6 & M \\
\hline
\end{tabular}

functionally opposite antibodies may explain the broad disease spectrum, from hyperthyroid to euthyroid or hypothyroid Graves' disease. The direct interactions of these antibodies at the monoclonal level remains to be examined. Recently, other investigators reported production of monoclonal human autoantibodies to TSHR using a similar method to ours; the EB virus transfomation of B lymphocytes and the separation of IgGsecreting $B$ lymphocytes with antihuman IgG-specific magnetic cell beads [49]. This approach should prove useful for obtaining these human monoclonal antibodies from Graves' patients. IgG class autoantibodies to the TSHR are a paradigm for humoral, organ-specific, autoimmune disease [50].

\section{TSHRAb genes}

We have previously analyzed variable regions of heavy-chain genes of 9 lymphocyte clones producing IgM class monoclonal TSHRAbs: 5 TBII clones and 4 TSAb clones [5, 36]. Recently, we extended these studies by analyzing, 1) more lymphocyte clones producing monoclonal TSHRAbs, 2) TSBAb clones, 3) clones producing IgG class TSHRAbs, and 4) variable regions of lightchain genes as well as heavy-chain genes. While, in the earlier study, genomic phage libraries derived from cloned lymphocytes were constructed and $\mathrm{V}_{\mathrm{H}}$ genes were isolated by screening with a $\mathrm{J}_{\mathrm{H}}$ probe, this time, the variable region genes of the Ig heavy and light chains of clones were isolated by the polymerase chain reaction method.

We aimed to clarify the following by analyzing Ig genes encoding TSHRAb: a) restricted usage of variable regions of Ig genes; b) somatic mutation of TSHRAb genes; $c$ ) difference among TBII, TSAb and TSBAb genes; and d) production of recombinant monoclonal TSHRAbs. B cell clones used for analyses are shown in Table 2. Six TSAb clones derived from Graves' patients and six clones from patients with primary hypothyroidism are added to the previous analysis, of which seven produce IgG class antibodies.

\section{a) Restricted $V_{H}$ and $V_{K}$ gene usage in TSHRAb}

Comparing nucleotide sequences of the $\mathrm{V}_{\mathrm{H}}$ or $V_{K}$ genes in TSHRAb clones with known germline $V_{H}$ or $V_{K}$ segments allowed us to identify the germ-line $V_{H}$ or $V_{K}$ segments used for the TSHRAb.

In $V_{H}$ genes, all TBII derived from Graves' patients were of $\mathrm{V}_{\mathrm{H}-\mathrm{III}}$, while those from patients with primary hypothyroidism were less restricted,

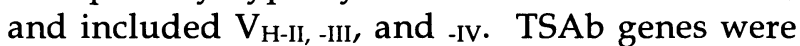
diverse and were of $\mathrm{V}_{\mathrm{H}-\mathrm{II}}$,-III, -IV and -V (Table 3). The most homologous germ-line $\mathrm{V}_{\mathrm{H}}$ segments of these antibodies have been used frequently in autoantibodies or in the fetal repertoire (Table 4) $[5,40,41]$. For example, V3-7, a germ-line $V_{H}$ counterpart of TBII (296-4), TSAb (101-2) and TSBAb (31-3), was reported to be expressed in fetal liver. The germ-line counterpart $\mathrm{V}_{\mathrm{H}}$ segment (V323) of 291-11, 267-9, 79-4 and 22-1 was also used in 18/2, an anti-DNA antibody, and 30P1 cDNA is found in fetal liver. Similarly, the germ-line $V_{H}$ segment of $82-1, \mathrm{~N}-2$ and B6B7 is V4-59 which is $99.4 \%$ homologous to $58 \mathrm{P} 2$, frequently expressed during the early stage of ontogeny, and $98.6 \%$ identical to Pag-1, an autoantibody for D-Ag of the Rh blood group system.

In $V_{K}$ genes, all TSBAb genes were of $V_{K-I I I}$, while TSHRAb genes from patients with Graves' disease, 
included $\mathrm{V}_{\mathrm{K}-\mathrm{I} \text {, -III }}$ and -IV, although the number of genes analyzed was small (Table 5) [40,41]. The most homologous germ-line $V_{K}$ segments of these antibodies have been used frequently in autoantibodies (Table 6) [40, 41]. For example, O2/ O12, which was the germ-line counterpart $V_{K}$ segment of TSAb (B6B7), has been reported to be used in pathologic human autoantibodies to the related i red blood cell antigens. A27, a germ-line $\mathrm{V}_{\mathrm{K}}$ counterpart of TSAb (101-2) and TSBAb (N-2), encodes many 17.109 cross-reactive idiotype (CRI)positive RF L chains in patients with autoimmune or lymphoproliferative diseases.

Thus, the fact that common germ-line $V_{H}$ and $\mathrm{V}_{\mathrm{K}}$ segments are used in TSHRAb, in other autoantibodies and in the fetal liver repertoire suggests that restricted $V_{H}$ and $V_{K}$ segments are selected for autoantibodies by unknown mechanisms and that there is a common mechanism for this selection.

b) Somatic mutations in TSAb, TBII and TSBAb

Somatic mutations of these clones were studied (Table 7). The considerable number of base changes in cDNA sequences encoding the mature $\mathrm{V}_{\mathrm{H}}$ and $\mathrm{V}_{\mathrm{K}}$ regions of these clones but not in those encoding the leader sequences suggests the accumulation of somatic mutations in $\mathrm{V}$ regions of $\operatorname{IgM}$ as well as IgG clones, although we cannot exclude the possibility that some are due to polymorphism.
This finding is compatible with a previous study in human IgM TSHRAbs [36], and again indicates the affinity maturation of TSHRAbs driven by antigen in IgM-producing lymphocytes. However, it is not clear whether the larger number of somatic mutations results in a higher affinity or activity of antibodies. To ascertain the presence of 'key mutations' which markedly increase the affinity of TSHRAbs will require extensive comparative analysis of different variable regions of TSHRAbs.

As mentioned above, both $V_{H}$ or $V_{K}$ can be used for either TBII, TSAb and TSBAb for different somatic mutations (Tables $4,6,7$ and 8). For example, V3-23 was used in two TBII clones (291-

Table 3. $\mathrm{V}_{\mathrm{H}}$ gene families of $\mathrm{B}$ cell clones producing TSHRAb

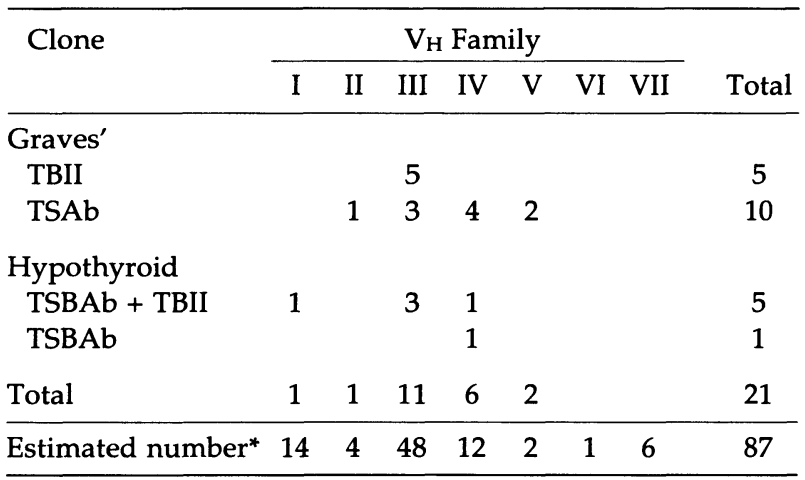

$\mathrm{V}_{\mathrm{H}}$ : variable segments of Ig heavy-chain genes. *: The number of $\mathrm{V}_{\mathrm{H}}$ segments on chromosome 14 is based on [63].

Table 4. Autoantibody $V_{H}$ genes and their homologous germline counterparts $[5,37,40,41]$

\begin{tabular}{|c|c|c|c|c|c|}
\hline \multirow[t]{3}{*}{ Germline $V_{H}$} & \multicolumn{4}{|c|}{ Clones } & \multirow{3}{*}{$\begin{array}{c}\text { Homologous cDNA for } \\
\text { autoantibodies }\end{array}$} \\
\hline & \multicolumn{2}{|c|}{ Graves' } & \multicolumn{2}{|c|}{ Hypothyroid } & \\
\hline & TBII & TSAb & TSBAb + TBII & TSBAb only & \\
\hline $3-7$ & $296-4$ & $101-2$ & $31-3$ & & (Fetal repertoire) \\
\hline $3-15$ & $296-1$ & & & & 4B4 (anti-Sm ab) \\
\hline $3-23$ & $\begin{array}{c}291-11 \\
267-9\end{array}$ & $\begin{array}{l}79-4 \\
22-1\end{array}$ & & & $\begin{array}{l}\text { 18/2 (anti-DNA ab) } \\
\text { Ab18 (polyreactive) } \\
\text { 30P1 (fetal liver) }\end{array}$ \\
\hline $3-53$ & $280-3$ & & & & (Fetal repertoire) \\
\hline $3-74$ & & & $39-1$ & & \\
\hline $4-31$ & & F3F3 & & & \\
\hline $4-39$ & & D11E2 & $32 \mathrm{~B}-2$ & & \\
\hline $4-59$ & & $\begin{array}{l}82-1 \\
\mathrm{~B} 6 \mathrm{~B} 7\end{array}$ & & $\mathrm{~N}-2$ & Pag1 (ab for D-antigen) \\
\hline $5-51$ & & $\begin{array}{l}141-1 \\
\text { G10C5 }\end{array}$ & & & $\begin{array}{l}\text { SA-1A (StrAb) } \\
\text { Ab2022 (anti-insulin ab) }\end{array}$ \\
\hline $1-18$ & & & $54-2$ & & IgM cold agglutinin \\
\hline $2-26$ & & $71-2$ & & & \\
\hline
\end{tabular}


11 and 267-9) and one TSAb clone (79-4). However, the positions and frequencies of somatic mutations differed among the three clones. In addition, the number of replacement $(R)$ mutations in CDR of 291-11 and 267-9 is twice that of 79-4. Also, V3-7 and $\mathrm{J}_{\mathrm{H}} 4$ are commonly used in TBII clone 296-4 [37] and TSAb clone 101-2 derived from the same patient. It is of note that the same combination of $\mathrm{V}_{\mathrm{H}}$ and $\mathrm{J}_{\mathrm{H}}$ segments confers different TSHRAb activities. Since clone 296-4 utilized a different $D_{H}$ segment and exhibited different frequencies and positions of somatic mutations from clone 101-2, the difference in their biological activity might be due to the usage of the $\mathrm{D}_{\mathrm{H}}$ segment, and/or somatic
Table 5. $V_{K}$ gene families of $B$ cell clones producing TSHRAb

\begin{tabular}{|c|c|c|c|c|c|c|c|c|}
\hline \multirow[t]{2}{*}{ Clone } & \multicolumn{7}{|c|}{$V_{K}$ Family } & \multirow[b]{2}{*}{ Total } \\
\hline & I & II & III & IV & $\mathrm{V}$ & VI & VII & \\
\hline \multicolumn{9}{|l|}{ Graves' } \\
\hline TBII & 1 & & 1 & 1 & & & & 3 \\
\hline $\mathrm{TSAb}$ & 2 & & 1 & 1 & & & & 4 \\
\hline \multicolumn{9}{|l|}{ Hypothyroid } \\
\hline $\mathrm{TSBAb}+\mathrm{TBII}$ & & & 1 & & & & & 1 \\
\hline TSBAb only & & & 1 & & & & & 1 \\
\hline Total & 3 & & 4 & 2 & & & & 9 \\
\hline Estimated number* & 29 & 27 & 14 & 1 & 1 & 3 & 1 & 76 \\
\hline
\end{tabular}

*: The number of $V_{K}$ segments is calculated from [64].

Table 6. Autoantibody $V_{K}$ genes and their homologous germline counterparts $[40,41]$

\begin{tabular}{|c|c|c|c|c|c|}
\hline \multirow[t]{3}{*}{ Germline $V_{K}$} & \multicolumn{4}{|c|}{ Clones } & \multirow{3}{*}{$\begin{array}{c}\text { Homologous cDNA for } \\
\text { autoantibodies }\end{array}$} \\
\hline & \multicolumn{2}{|c|}{ Graves' } & \multicolumn{2}{|c|}{ Hypothyroid } & \\
\hline & TBII & TSAb & TSBAb + TBII & TSBAb only & \\
\hline A27 & & $101-2$ & $32 \mathrm{~A}-5$ & & $\mathrm{RF}$ \\
\hline B3 & $296-1$ & $82-1$ & & & frequent in autoimmunity \\
\hline L5 & 291-11 & & & & \\
\hline L6 & $267-9$ & & & $\mathrm{~N}-2$ & $\mathrm{RF}$ \\
\hline $\mathrm{O} 2 / \mathrm{O} 12$ & & B6B7 & & & Anti-i RBC Ab \\
\hline HUMIGKLVJ & & $141-1$ & & & Anti-i RBC Ab, RF \\
\hline
\end{tabular}

Table 7. Somatic changes in the $\mathrm{V}_{\mathrm{H}}$ coding regions of TSHRAb

\begin{tabular}{|c|c|c|c|c|c|c|}
\hline \multirow[t]{2}{*}{ Clone } & \multirow{2}{*}{$\begin{array}{l}\text { TSHRAb } \\
\text { activity }\end{array}$} & \multirow{2}{*}{$\begin{array}{c}\mathrm{Ig} \\
\text { isotype }\end{array}$} & \multicolumn{2}{|c|}{ Homology } & \multicolumn{2}{|c|}{$\mathrm{R} / \mathrm{S}$} \\
\hline & & & nucleotides & amino acids & FR & CDR \\
\hline 291-11 & TBII & M & $280 / 299(93.6 \%)$ & $91 / 96(94.8 \%)$ & $2 / 6$ & $6 / 2$ \\
\hline 296-1 & TBII & $\mathbf{M}$ & $85 / 303(94.0 \%)$ & $88 / 100(88 \%)$ & $9 / 4$ & $5 / 0$ \\
\hline $296-4$ & TBII & $\mathbf{M}$ & $287 / 298(96.3 \%)$ & $95 / 99(96 \%)$ & $3 / 4$ & $2 / 2$ \\
\hline $267-9$ & TBII & $\mathbf{M}$ & $280 / 295(94.9 \%)$ & $88 / 97(90.7 \%)$ & $5 / 3$ & $6 / 0$ \\
\hline $280-3$ & TBII & M & $278 / 296(93.9 \%)$ & $84 / 96(87.5 \%)$ & $8 / 4$ & $6 / 0$ \\
\hline $141-1$ & TSAb & M & $292 / 300(97.3 \%)$ & $94 / 98(95.9 \%)$ & $2 / 3$ & $2 / 1$ \\
\hline $82-1$ & TSAb & $M$ & $279 / 293(95.2 \%)$ & $87 / 96(90.6 \%)$ & $7 / 3$ & $2 / 2$ \\
\hline $71-2$ & TSAb & $M$ & $298 / 300(99.3 \%)$ & $98 / 100(98 \%)$ & $1 / 0$ & $1 / 0$ \\
\hline $79-4$ & $\mathrm{TSAb}$ & $M$ & $303^{*} / 309(98.1 \%)$ & $95 / 98(96.9 \%)$ & $1 / 1$ & $3 / 0$ \\
\hline $101-2$ & TSAb & $\mathbf{M}$ & $276 / 294(94 \%)$ & $89 / 98(90 \%)$ & $6 / 8$ & $5 / 0$ \\
\hline $22-1$ & $\mathrm{TSAb}$ & $M$ & $265 / 291(91 \%)$ & $80 / 97(82 \%)$ & $11 / 7$ & $9 / 1$ \\
\hline B6B7 & $\mathrm{TSAb}$ & G & $288 / 293(98.3 \%)$ & $93 / 97(95.9 \%)$ & $1 / 1$ & $2 / 0$ \\
\hline F3F3 & TSAb & G & $276 / 299(92.3 \%)$ & $87 / 99(89.9 \%)$ & $7 / 10$ & $5 / 1$ \\
\hline G10C5 & TSAb & G & $285 / 294(96.9 \%)$ & $92 / 98(93 \%)$ & $7 / 0$ & $2 / 0$ \\
\hline D11E2 & $\mathrm{TSAb}$ & G & $276 / 297(92.9 \%)$ & $92 / 99(93 \%)$ & $10 / 8$ & $3 / 0$ \\
\hline $\mathrm{N}-2$ & TSBAB & G & $266 / 291(91.8 \%)$ & $84 / 97(87 \%)$ & $10 / 5$ & $4 / 2$ \\
\hline $54-2$ & $\mathrm{TSBAb}+\mathrm{TBII}$ & G & $291 / 294(99.0 \%)$ & $95 / 98(97 \%)$ & $2 / 0$ & $1 / 0$ \\
\hline $32 \mathrm{~B}-2$ & $\mathrm{TSBAb}+\mathrm{TBII}$ & $M$ & $295 / 297(99.3 \%)$ & $97 / 99(98 \%)$ & $1 / 0$ & $1 / 0$ \\
\hline $39-1$ & $\mathrm{TSBAb}+\mathrm{TBII}$ & $M$ & $287 / 294(97.6 \%)$ & $95 / 98(97 \%)$ & $2 / 1$ & $2 / 1$ \\
\hline $31-3$ & $\mathrm{TSBAb}+\mathrm{TBII}$ & M & $276 / 284(94.2 \%)$ & $90 / 98(92 \%)$ & $4 / 7$ & $4 / 1$ \\
\hline
\end{tabular}

$\mathrm{R}$, replacement mutations; $\mathrm{S}$, silent mutations; $\mathrm{FR}$, framework; $\mathrm{CDR}$, complementarity determining region. 
Table 8. Somatic changes in the $\mathrm{V}_{\mathrm{K}}$ coding regions of TSHRAb

\begin{tabular}{lcccccc}
\hline \multirow{2}{*}{ Clone } & \multirow{2}{*}{ TSHRAb } & Ig & \multicolumn{2}{c}{ Homology } & \multicolumn{2}{c}{ R/S } \\
\cline { 5 - 6 } & activity & isotype & nucleotides & amino acids & FR & CDR \\
\hline $291-11$ & TBII & M & $97.9 \%$ & $93.7 \%$ & $2 / 0$ & $3 / 1$ \\
$296-1$ & TBII & M & $96.7 \%$ & $94.1 \%$ & $4 / 1$ & $3 / 1$ \\
$296-4$ & TBII & M & $97.9 \%$ & $96.8 \%$ & $1 / 0$ & $3 / 2$ \\
$267-9$ & TBII & M & $97.9 \%$ & $94.7 \%$ & $2 / 0$ & $3 / 0$ \\
$280-3$ & TBII & M & $97.9 \%$ & $93.7 \%$ & $2 / 0$ & $3 / 1$ \\
$141-1$ & TSAb & M & $95.4 \%$ & $90.5 \%$ & $4 / 1$ & $7 / 1$ \\
$82-1$ & TSAb & M & $98.0 \%$ & $95.0 \%$ & $4 / 0$ & $2 / 0$ \\
B6B7 & TSAb & G & $97.9 \%$ & $94.7 \%$ & $3 / 0$ & $2 / 1$ \\
$101-2$ & TSAb & M & $97.9 \%$ & $94.7 \%$ & $3 / 0$ & $2 / 1$ \\
$32 \mathrm{~A}-5$ & TSBAb+TBII & G & $98.3 \%$ & $94.8 \%$ & $2 / 0$ & $3 / 0$ \\
N-2 & TSBAb & G & $97.5 \%$ & $95.8 \%$ & $2 / 0$ & $4 / 1$ \\
\hline
\end{tabular}

mutations. The light chain of $296-4$ has not been characterized, so the involvement of the light chain sequence is also conceivable. These results clearly indicate that the germ-line $V_{H}$ can be used for either TBII or TSAb for different somatic mutations.

\section{c) Production of recombinant TSHRAb}

Next, we aimed to produce recombinant TSHRAb proteins [40]. For this purpose, we isolated $\mathrm{V}$ region cDNAs of both $\mathrm{H}$ and light chains of IgM and IgG TSHRAbs from $B$ cell clones including those already established [37, 38]. Each pair of $\mathrm{H}$ - and L-chain cDNAs was ligated into novel expression vectors for $\mathrm{IgG}_{1}$ production and introduced into myeloma cells (Fig. 3) [40]. In two transfectants, derived from B6B7 and 101-2 clone, recombinant IgG $_{1}$ antibodies with significant TSAb activities were successfully obtained (Fig. 4) [40]. The TSAb activity is reported to be confined to the $I_{g} G_{1}$ fraction of patient's serum [51]. IgGs derived from B6B7 and 101-2 Ig gene transfectants exhibited significant TSAb activity in FRTL-5 cells, while IgG derived from transfectants with an indifferent Ig gene did not. The results were reproduced in TSAb assays using $\mathrm{CHO}$ cells transfected with rat TSHR cDNA.

The supernatant of $\mathrm{B} 6 \mathrm{~B} 7$ transfectant gave significant TSAb activity between the IgG concentrations of $15-240 \mu \mathrm{g} / \mathrm{ml}$, with maximal activity obtained at around $30 \mu \mathrm{g} / \mathrm{ml}[40]$. The range of maximal TSAb activity of B6B7 in four experiments was $186-302$ (mean \pm SD: $239 \pm 41$ )\%. This activity was not only very similar to that of the supernatant of original EBV-transformant (202-
285 (mean \pm SD: $240 \pm 34) \%$, [39]), but also appeared to reflect that of the patient serum (263\% [39]). When the $V_{H}$ region of $B 6 B 7$ in the construct was replaced with an unrelated $V_{H}$ region, which utilized the same germline $\mathrm{V}_{\mathrm{H}}$ (V4-59) yet different $D_{H}$ and $J_{H}, T S A b$ activity was lost. On the other hand, TSAb activity of 101-2 IgG was observed between 10 to $80 \mu \mathrm{g} / \mathrm{ml}$. Of note, the range of maximal TSAb activity at around $15 \mu \mathrm{g} / \mathrm{ml}$ in four experiments was 181-239 (mean \pm SD: $212 \pm 24$ )\%, and slightly lower than that of the original EBV transformant (334\%). This might be due to the alteration of isotype from IgM to $\mathrm{IgG}_{1}$.

The level of TSAb activity was dose-dependent in both clones and TSAb activity levels decreased at higher IgG concentrations than the maximal point. Thus, in both antibodies, dose-dependency curves of TSAb activities were bell-shaped, although the implications of this phenomenon remain unclear. We tested whether or not these TSAbs also possessed TBII activity. No TBII activity was detected even at the IgG concentrations that gave significant TSAb activity, in agreement with the results obtained in the supernatants of EBV transformants, indicating that TSAb and TBII activities are derived from separate $B$ lymphocyte clones [40].

Genetic engineering of monoclonal TSAbs enables large amounts of TSAb protein to be produced. Since the TSAbs isolated here were derived from patient lymphocytes, they should prove useful as a biological standard for TSAbs in various fields of research and facilitate pathophysiological studies on TSHRAbs in autoimmune thyroid diseases. 


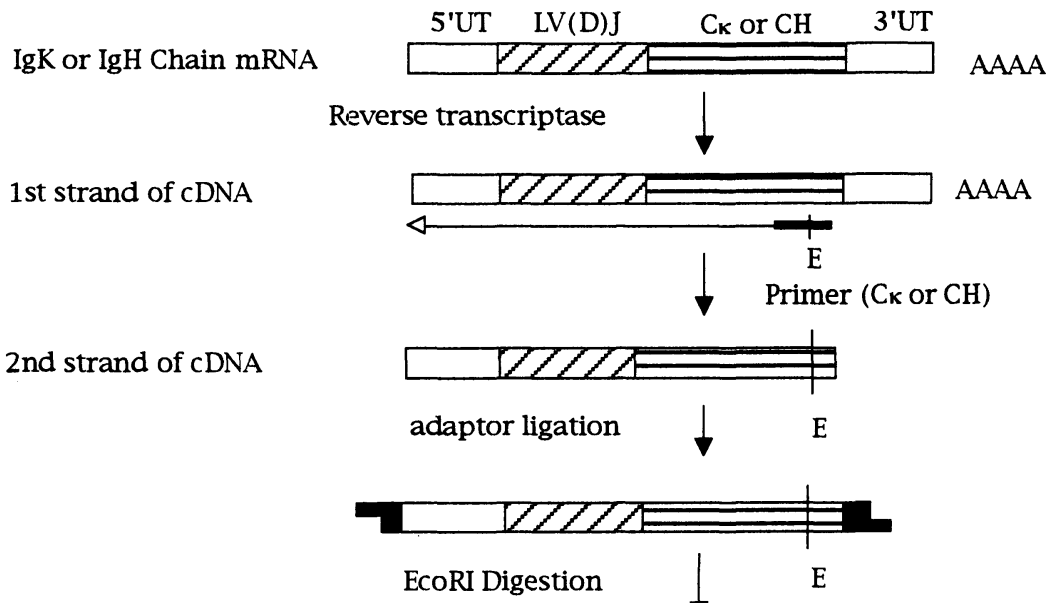

Amplify VK or VH cDNAs
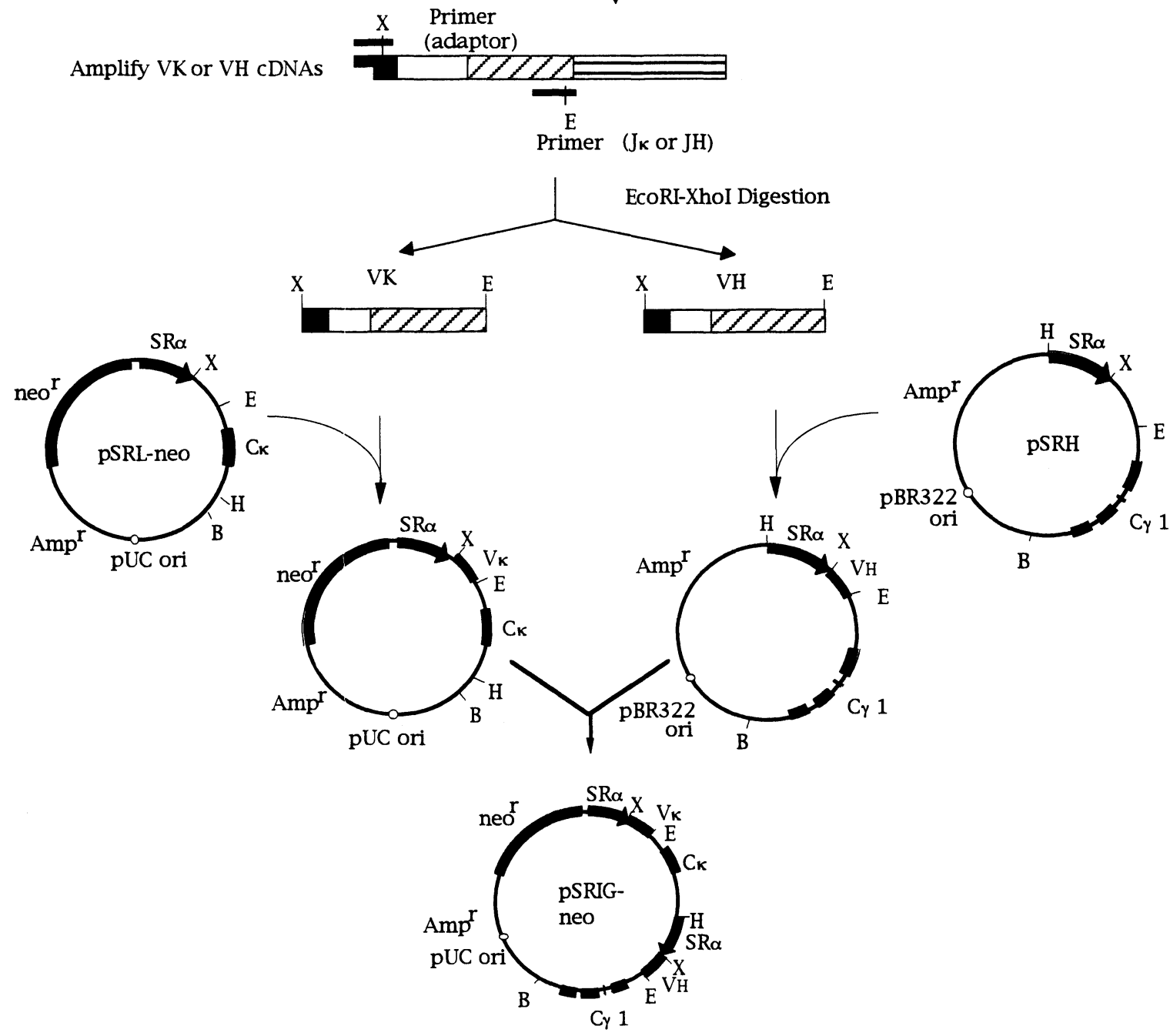

Fig. 3. An outline of the isolation of $V_{H}$ and $V_{K}$ genes from mRNAs of $B$ cell clones, and construction of recombinant Ig genes [40]. UT, untranslated region; L, leader; V, variable; D, diverse; J, joining; C, constant; AAAA, poly A tail; SR $\alpha, S R \alpha$ promoter; heavy line, exon; E, EcoRI; $B, B a m H I ; H$, HindIII; $X$, XhoI. 


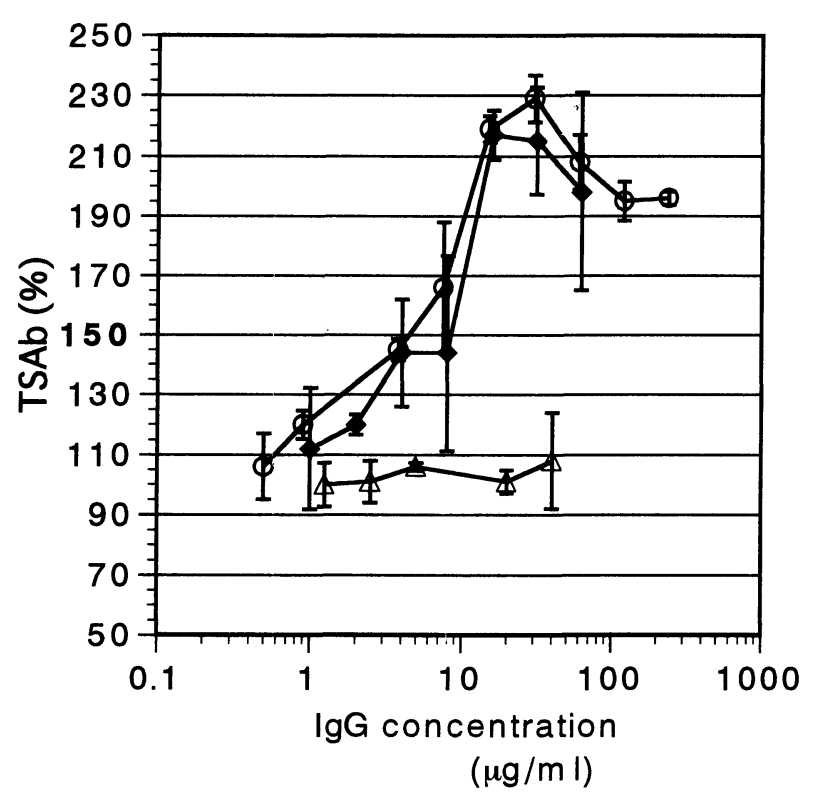

Fig. 4. TSAb activities of recombinant anti-TSHRAbs produced in myeloma cells [40]. B6B7, $\mathrm{O} ; 101-2$, The activities were expressed as the percentage of generated cAMP relative to modified Hank's medium. The 196-14 recombinant chimeric antibody $\left(\mathrm{IgG}_{1}\right)(\triangle)$ against ovarian cancerassociated antigen (CA125), which is not related to the TSHRAb activity, was used as a negative control. These data represent one of four different experiments using FRTL- 5 cells with similar results and are expressed as mean \pm SD. Each experiment was performed in triplicate wells.

\section{Others}

a) $\mathrm{T}$ cell

It is important to define T cell epitopes on TSHR, since it is expected to lead to further understanding of the pathogenesis of Graves' disease and to new developments in immunotherapy. Little is known, however, about $\mathrm{T}$ cell recognition of TSHR [5]. Although the existence of multiple $T$ cell epitopes on the receptor is suggested, no definite epitopes have been determined to date.

Recently, subsets of $\mathrm{CD}^{+}$helper $\mathrm{T}$ cells distinguishable by the cytokines they produce have been described: Th1 cells that produce interleukin (IL)-2, interferon (IFN) $\gamma$ and tumor-necrosis factor (TNF)- $\beta$, and Th2 cells that produce IL-4, IL-5, IL-6 and IL-13 [52, 53]. Interestingly, the Th1/Th2 dichotomy may provide an insight into immunological determinants of disease. Indeed, there is evidence that the outcome of autoimmune disorders is linked to Th1- and Th-2 like cytokine expression patterns and to the particular T-cell subset induced. Although the initial proposal that Th1 and Th2 cells were primarily responsible for cell mediated and humoral immunity, respectively, is an oversimplification of T-cell effector functions, some antibody-mediated autoimmune diseases, such as Graves' disease may be caused by Th2induced antibodies.

b) Cytokines and costimulatory molecules

Associations between T-cell subset cytokine expression patterns and autoimmune diseases underscore the critical roles played by cytokines in controlling pathological immune responses [52, 53]. IL-4 and IL-13 faciliate a Th2 response resulting in antibody synthesis and IL-4 itself is a key cytokine product of Th2 cells for this response. A recent study showed the majority of thyroid tissue specimens obtained from Graves' patients expressed these cytokines [54].

Interactions between the B7s (B7-1 and B7-2) on antigen-presenting cells and CD28 or CTLA4 on T cells are important for $\mathrm{T}$ cell activation; CD28 plays a critical role for preventing $\mathrm{T}$ cell unresponsiveness, while CTLA-4 is supposed to be a negative regulator of ongoing immune responses, although it is not clear how such costimulatory interactions influence on a response of either Th1 or Th2 [55]. Additionally, costimulatory molecules are reported to be important for antigen presentation by follicular cells that express MHC class II molecules aberrantly in autoimmune diseases [55]. Furthermore, as mentioned earlier, CTLA-4 alanine- 17 confers genetic susceptibility to Graves' disease [30]. This dimorphism results in an amino acid exchange (Thr/Ala) in the leader peptide of the expressed protein, suggesting an alteration of CTLA-4 function. Thus, cytokines and costimulatory molecules appear to play an important role in a pathophysiological process of Graves' disease.

\section{Epilogue}

The next goal is to generate an animal model of Graves' disease. Most attempts to develop such a model by immunizing animals with TSHR protein 
or peptides have failed. Recently, Shimojo et al. induced Graves-like disease in mice by immunizing them with fibroblasts transfected with TSHR and MHC class II molecule [56]. They developed hyperthyroidism with the major humoral and histological features of Graves' disease. However, this model is not inheritable. In this regard, an animal model in which the disease is genetically programed is awaited. For this purpose, we hope to introduce immunoglobulin genes into transgenic mice, since a similar attempt succeeded in a model of autoimmune hemolytic anemia $[57,58]$.

Finally, the pathogenesis of extrathyroidal manifestations has yet to be clarified. There have been several reports demonstrating TSHR transpripts, TSHR protein or a cross-reacting protein in a variety of extratyroidal tissues, including ocular tissue, dermal firbroblasts, lymphocytes, skeletal muscle and heart [59-62]. It is, however, not clear how TSHR plays a role as the antigenic link between the thyroid and other tissues which might explain the frequent association of Graves' disease and extrathyroidal manifestations. The mechanism for the association of these disorders with TSHR for antibodies and $\mathrm{T}$ lymphocytes in the involved tissues has to be elucidated.

\section{Acknowledgments}

Studies described here were done in collaboration with Department of Laboratory Medicine, and Department of Medical Chemistry, Kyoto University Graduate School of Medicine, and Center for Molecular Biology and Genetics, and Kyoto University School of Medicine. We thank Drs. Fumihiko Matsuda, Jyoji Okuda, Hua Li, Hideo Sugawa, Euy Kyun Shin and Tasuku Honjo. The TSHR polymorphism study was done in collaboration with Drs. Michele Sale and Donald W Bowden.

This work was partly supported by grants in aid from the Ministry of Education, Science and Culture of Japan (No. 05671922, 07672487, 08557150, 08671150), the Ryoichi Naito Foundation for Medical Research, the Kurozumi Medical Foundation, the Kato Memorial Trust for Nambyo Research, the Yamanouchi Foundation for Research on Metabolic Disorders, the Uehara Memorial Foundation and a grant from the Dr. Shimizu Foundation for the Promotion of Immunology Research Grant for 1996 to TA.

\section{References}

1. Davies TF (1996) Graves' disease. In: Braverman LE, Utiger RD (eds) Werner and Ingbar's The Thyroid. 7th ed, Lippencott, Philadelphia: 525-536.

2. Burman KD, Baker Jr JR (1985) Immune mechanisms in Graves' disease. Endocr Rev 6: 183-2323.

3. Rees-Smith B, McLachlan SM, Furmaniak J (1988) Autoantibodies to the thyrotropin receptor. Endocr Rev 9: 106-121.

4. Mori T, Akamizu T, Kosugi S, Sugawa H, Inoue D, Okuda J, Ueda Y. (1994) Recent progress in TSH receptor studies with a new concept of “autoimmune TSH receptor disease". Endocr J 41: 1-11.

5. Akamizu T, Kohn LD, Mori T (1995) Molecular studies on thyrotropin (TSH) receptor and anti-TSH receptor antibodies. Endocr J 42: 617-627.

6. Volpé R (1991) Graves' disease. In: Braverman LE, Utiger RD (eds) Werner and Ingbar's The Thyroid. 7th ed, Lippencott, Philadelphia: 648-657.

7. Skillern PG (1972) Genetics of Graves' disease. Mayo Clin Proc 47: 848-849.

8. Mckenzie JM, Zakarija M (1989) Hyperthyroidism. In: DeGroot LJ, Besser GM, Cahill GF, Marshall JC,
Nelson DH, Odell WD, Potts JT, Rubenstein AH, Steinberger E (eds) Endocrinology. Saunders, Philadelphia: 646-682.

9. Uno H, Sasazuki T, Tamai H, Matsumoto H (1981) Two major genes, linked to HLA and Gm, control susceptibility to Graves' disease. Nature 292: 768770.

10. Cuddihy RM, Dutton CM, Bahn RS (1995) A polymorphism in the extracellular domain of the thyrotropin receptor is highly associated with autoimmune thyroid disease in females. Thyroid 5: 89-95

11. Yanagawa T, Hidaka $Y$, Guimaraes V, Soliman $M$, DeGroot LJ (1995) CTLA-4 gene polymorphism associated with Graves' disease in a Caucasian population. J Clin Endocrinol Metab 80: 41-45.

12. Blakemore AIF, Watson PF, Weetman AP, Duff GW (1995) Association of Graves' disease with an allele of the interleukin-1 receptor antagonist gene. J Clin Endocrinol Metabol 80: 111-115.

13. Payami H, Joe S, Farid NR, Stenszky V, Chan SH, Yeo PPB, Cheah JS, Thomson G (1989) Relative predispositional effects (RPEs) of marker alleles 
with disease: HLA-DR alleles and Graves Disease. Am J Hum Genet 45: 541-546.

14. Farid, NR, Sampson L, Noel EP, Barnard JM, Mandeville R, Larsen B, Marshall WH (1979) A study of human leukocyte $D$ locus related antigens in Graves' disease. J Clin Invest 63: 108-113.

15. Allannic H, Fauchet R, Lorcy $Y$, Heim J, Gueguen M, Leguerrier A-M, Genetet B (1980) HLA and Graves' disease: An association with HLA-DRw3. J Clin Endocrinol Metab 51: 863-867.

16. Roman SH, Greenberg D, Rubinstein P, Wallenstein S, Davies TF (1992) Genetics of autoimmune thyroid disease: Lack of evidence for linkage to HLA within families. J Clin Endocrinol Metab 74: 496-503.

17. Wilkin G (1990) The primary lesion theory of autoimmunity: A speculative hypothesis. Autoimmunity 7: 225-235.

18. Wick G, KrömerG, Neu N, Fässler R, Ziemiecki A, Müller RG, Ginzel M, Béládi I, Kühr T, Hála K (1987) The multi-factorial pathogenesis of autoimmune disease. Immunol Lett 16: 249-258.

19. Akamizu T, Sale MM, Yokota T, Nakao K, Mori T, Iwasaki $\mathrm{H}$, Yoshimura $\mathrm{H}$, Ito $\mathrm{K}$, Rich SS, JenningsGee JE, Bowden DW (1997) Isolation of a microsatellite marker for the thyrotropin receptor gene and its association with autoimmune thyroid diseases in a Japanese population. Thyroid (suppl) (In press).

20. Sale MM, Akamizu T, Howard TD, Yokota T, Nakao $\mathrm{K}$, Mori T, Iwasaki H, Rich SS, Jennings-Gee JE, Yamada M, Bowden DW (1997) Association of autoimmune thyroid disease with a microsatellite marker for the thyrotropin receptor gene and CTLA4 in a Japanese population. Proc Assoc Amer Physicians 109: 453-461.

21. Libert, F, Passage E, Lefort A, Vassart G, Mattei M$G$ (1990) Localization of human thyrotropin receptor gene to chromosome region $14 \mathrm{q} 31$ by in situ hybridization. Cytogenet Cell Genet 54: 82-83.

22. Rousseau-Merck, MF, Misrahi M, Loosfelt H, Atger M, Milgrom E, Berger R (1990) Assignment of the human thyroid stimulating hormone receptor (TSHR) gene to chromosome 14q31. Genomics 8: 233236.

23. Akamizu T, Ikuyama S, Saji M, Kosugi S, Kozak C, McBride WO, Kohn LD (1990) Cloning, chromosomal assignment, and regulation of the rat thyrotropin receptor: Expression of the gene is regulated by thyrotropin, agents that increase cAMP levels, and thyroid autoantibodies. Proc Natl Acad Sci USA 87: 5677-5681.

24. Heldin N-E, Gustavsson B, Westermark K, Westermark B (1991) A somatic point mutation in a putative ligand binding domain of the TSH receptor in a patient with autoimmune hyperthyroidism. $J$ Clin Endocrinol Metab 73: 1374-1376.

25. Bohr URM, Behr M, Loos U (1993) A heritable point mutation in an extracellular domain of the TSH receptor involved in the interaction with Graves' immunoglobulins. Biochim Biophys Acta 1216: 504505.

26. Bahn RS, Dutton CM, Heufelder AE, Sarkar G (1994) A genomic point mutation in the extracellular domain of the thyrotropin receptor in patients with Graves' ophthalmopathy. J Clin Endocrinol Metab 78: 256-260.

27. Nisticò L, Buzzetti R, Pritchard LE, Van der Auwera B, Giovannini C, Bosi E, Martinez Larrad MT, Serrano Rios M, Chow CC, Cockram CS, Jacobs K, Mijovic C, Bain SC, Barnett AH, Vandewalle CL, Schuit F, Gorus FK, Belgian Diabetes Registry, Tosi R, Pozzilli P, Todd JA (1996) The CTLA-4 gene region of chromosome $2 \mathrm{q} 33$ is linked to, and associated with, type 1 diabetes. Hum Molec Genet 5: 1075-1080.

28. Harper K, Balzano C, Rouvier E, Mattéi M-G, Luciani M-F, Golstein P (1991) CTLA-4 and CD28 activated lymphocyte molecules are closely related in both mouse and human as to sequence, message expression, gene structure, and chromosomal location. J Immunol 147: 1037-1044.

29. Buonavista N, Balzano C, Pontarotti P, Le Paslier $D$, Golstein P (1992) Molecular linkage of the human CTLA4 and CD28 Ig-superfamily genes in yeast artificial chromosomes. Genomics 13: 856-861.

30. Donner H, Rau H, Walfish PG, Braun J, Siegmund $\mathrm{T}$, Finke R, Herwig J, Usadel KH, Badenhoop K (1997) CTLA4 alanine-17 confers genetic susceptibility to Graves' disease and to type 1 diabetes mellitus. J Clin Endocrinol Metab 82: 143146.

31. Benvenga S (1996) Benzodiazepine and remission of Graves' disease. Thyroid 6: 659-660.

32. Dai G, Levy O, Carrasco N (1996) Cloning and characterization of the thyroid iodide transporter. Nature 379: 458-460.

33. Sinha AA, Lopez T, McDevitt (1990) Autoimmune diseases: The failure of self tolerance. Science 248: 1380-1388.

34. Nossai GJV (1994) Negative selection of lymphocytes. Cell 76: 229-239.

35. Nagayama Y, Rapoport B (1992) The thyrotropin receptor 25 years after its discovery: New insight after its molecular cloning. Mol Endocrinol 6: 145156.

36. Kohn LD, Kosugi S, Ban T, Saji M, Ikuyama S, Giuliani C, Hidaka A, Shimura H, Akamizu T, Tahara K, Moriarty J, Prabhakar BS, Singer DS (1992) Molecular basis for the autoactivity against thyroid stimulation hormone receptor. Intern Rev Immunol 9: 135-165.

37. Shin EK, Akamizu T, Matsuda F, Sugawa $H$, Fujikura J, Mori T, Honjo T (1994) Variable-regions of immunoglobulin heavy-chain genes encoding 
antithyrotropin (TSH) receptor antibodies of patients with Graves' disease. J Immunol 152: 14851492.

38. Okuda J, Akamizu T, Sugawa H, Matsuda F, Li H, Mori T (1994) Preparation and characterization of monoclonal antithyrotropin receptor antibodies obtained from peripheral lymphocytes of hypothyroid patients with primary myxedema. J Clin Endocrinol Metab 79: 1600-1604.

39. Li H, Akamizu T, Okuda J, Sugawa H, Matsuda F, Tsubata T, Mori T (1995) Isolation of Epstein-Barr virus-transformed lymphocytes producing IgG class monoclonal antibodies using a Magnetic Cell separator (MACS): Preparation of thyroidstimulating IgG antibodies from patients with Graves' disease. Biochem Biophy Res Commun 207: 985-993.

40. Akamizu T, Matsuda F, Okuda J, Li H, Kanda H, Watanabe T, Honjo T, Mori T (1996) Molecular analysis of stimulatory antithyrotropin receptor antibodies (TSAbs) involved in Graves' disease: Isolation and reconstruction of antibody genes, and production of monoclonal TSAbs. J Immunol 157: 3148-3152.

41. Okuda J, Akamizu T, Matsuda F (1995) Variable regions of immunoglobulin genes encoding "blocking type" antithyrotropin recepter antibodies of patients with primary myxedema. Thyroid 5 (suppl 1): S-210 (abst).

42. Valente WA, Vitti P, Yavin Z, Yavin E, Rotella CM, Grollman EF, Toccafondi RS, Kohn LD (1982) Monoclonal antibodies to the thyrotropin receptor: Stimulating and blocking antibodies derived from the lymphocytes of patients with Graves' disease. Proc Natl Acad Sci USA 79: 6680-6684.

43. Yoshida T, Ichikawa Y, Ito K, Homma M (1988) Monoclonal antibodies to the thyrotropin receptor bind to a 56-KDa subunit of the thyrotropin receptor and show heterogeneous bioactivities. J Biol Chem 263: 16341-16347.

44. Baker JR, Saunders NR, Kaulferoch W, Burman KD (1988) Development of a human monoclonal antibody from a Graves' disease patient that identifies a novel thyroid membrane antigen. $J$ Immunol 140: 2593-2599.

45. Kohn LD, Valente WA, Lacetti P, Cohen JL, Aloj SM, Grollman EF (1983) Multicomponent structure of the thyrotropin receptor: Relationship to Graves' disease. Life Sci 32: 15-30.

46. Takeda K, Takamatsu J, Kasagi K, Sakane S, Ikegami Y, Isotani H, Majima T, Kitaoka H, Iida Y, Ikekubo K, Konishi J, Mozai T (1988) Development of hyperthyroidism following primary hypothyroidism: A case report with changes in thyroid-related antibodies. Clin Endocrinol 28: 341-344.

47. Miyauchi A, Amino N, Tamaki H, Kuma K (1988) Coexistence of thyroid-stimulating and thyroid- blocking antibodies in a patient with Graves' disease who had transient hypothyroidism. Am J Med 85: 418-420.

48. Tamai H, Kasagi K, Takaichi Y, Takamatsu J, Komaki G, Matsubayashi S, Konishi J, Kuma K, Kumagai LF, Nagataki S (1989) Development of spontaneous hypothyroidism in patients with Graves' disease treated with antithyroidal drugs: Clinical, immunological, and histological findings in 26 patients. J Clin Endocrinol Metab 69: 49-53.

49. Morgenthaler NG, Kim MR, Tremble J, Huang GC, Richter W, Gupta M, Scherbaum WA, McGregor AM, Banga JP (1989) Human IgG autoantibodies to the thyrotropin receptor from Epstein-Bar virus transformed B lymphocytes: Characterization by immunoprecipitation with recombinant antigen, and biological activity. J Clin Endocrinol Metab 81: 3155-3161.

50. McLachlan SM, Rapoport B (1996) Editorial: Monoclonal, human autoantibodies to the TSH receptor-The holy grail and why are we looking for it? J Clin Endocrinol Metab 81: 3152-3154.

51. Weetman AP, Yateman ME, Ealey PA, Black C, Reimer CB, Williams RC, Shine B, Marshal NJ (1990) Thyroid-stimulating antibody activity between different immunoglobulin G subclasses. J Clin Invest 86: 723-727.

52. Abbas AK, Murphy KM, Sher A (1996) Functional diversity of helper T lymphocytes. Nature 383: 787793.

53. Finkelman FD (1995) Relationships among antigen presentation, cytokines, immune deviation, and autoimmune disease. J Exp Med 182: 279-282.

54. Ajjan RA, Watson PF, Weetman AP (1997) Detection of IL-12, IL-13, and IL-15 messenger ribonucleic acid in the thyroid of patients with autoimmune thyroid disease. J Clin Endocrinol Metab 82: 666-669.

55. Lombarde G, Arnold K, Uren J, Marelli-Berg F, Hargreaves R, Imami N, Weetman A, Lechler R (1997) Antigen presentation by interferon- $\gamma$-treated thyroid follicular cells inhibits interleukin-2 (IL-2) and supports IL-4 production by B7-dependent human T cell. Eur J Immunol 27: 62-71.

56. Shimojo N, Kohno Y, Yamaguchi KI, Kikuoka SI, Hoshioka A, Niimi H, Hirai A, Tamura Y, Saito Y, Kohn LD, Tahara K (1996) Induction of Graves-like disease in mice by immunization with fibroblasts transfected with the thyrotropin receptor and class II molecule. Proc Natl Acad Sci USA 93: 11074-11079.

57. Okamoto M, Murakami M, Shimizu A, Ozaki S, Tsubata T, Kumagai S, Honjo T (1992) A transgenic model of autoimmune hemolytic anemia.J Exp Med 175: 71-79.

58. Murakami M, Tsubata T, Okamoto M, Shimizu A, Kumagai S, Imura H, Honjo T (1992) Antigeninduced apoptotic death of Ly-1 B cells responsible for autoimmune disease in transgenic mice. Nature 
357: 77-80.

59. Wall J (1995) Extrathyroidal manifestations of Graves' disease. J Clin Endocrinol Metab 80: 34273429.

60. Paschke R, Vassart G, Ludgate M (1995) Current evidence for and against the TSH receptor being the common antigen in Graves' disease and thyroid associated ophthalmopathy. Clin Endocrinol 42: 565569.

61. Davies TF (1994) The thyrotropin receptors spread themselves around. J Clin Endocrinol Metab 79: 31232-31233.
62. Koshiyama H, Sellitti DF, Akamizu T, Doi SQ, Takeuchi Y, Inoue D, Sakaguchi H, Takemura G, Sato Y, Takatsu Y, Nakao K (1996) Cardiomyopathy associated with Graves' disease. Clinical Endocrinol 45: 111-116.

63. Honjo T, Matsuda F (1995) Immunoglobulin heavy chain loci of mouse and human. In: Honjo T, Alt FW (eds) Immunoglobulin Genes. 2nd ed, Academic Press, London: 145-171.

64. Zahau HG (1995) The human immunoglobulin $\mathrm{k}$ genes. In: Honjo T, Alt FW (eds) Immunoglobulin Genes. 2nd ed, Academic Press, London: 173-191. 